\title{
Developing Motion Sensor Experiments in Problem Based Learning for Students' HOTS
}

\author{
Johri Sabaryati ${ }^{1 *}$, Sparisoma Viridi ${ }^{2}$ Linda Sekar Utami ${ }^{1,}$ Zulkarnain $^{1,}$ M.Isnaini ${ }^{1}$ \\ ${ }^{1}$ Universitas Muhammadiyah Mataram, Indonesia \\ ${ }^{2}$ Institut Teknologi Bandung, Indonesia \\ *Corresponding author. Email: joyafarashy@gmail.com
}

\begin{abstract}
This study had objectives of (1) representing students' HOTS, (2) developing motion sensor experiments based computerized and sensor in problem-based learning, and (3) testing effectiveness motion sensor experiments for students' higher order thinking skills (HOTS). This method used research and development (R \& D) with the Borg and Gall development model. The Effectiveness of rolling motion for students'HOTS employs pre-test post-test control group design. The research subjects were 41 students of Madrasyah Aliyah Narmada in West Lombok Regency, obtained by a random sampling technique. The testing instrument were the product validation questionnaire and HOTS essay tests. The data were analyzed using the five scales qualitative technique and gain score. Findings show that: (1) The highest percentage of students' HOTS lies in the "Low" categories $(66 \%)$, while medium categories amount to 14\%; (2) based on expert validation, motion sensor experiments in Problem Based Learning is worth using; and (3) The category using motion sensor experiments for students' HOTS is medium.
\end{abstract}

Keywords: higher order thinking skill, motion sensor experiments

\section{INTRODUCTION}

Today the technological revolution is taking place very quickly in various areas of life. [1]. One of these is the education sector [2]. In the 21st century, in the Industry 4.0 and Society 5.0 (civilization revolution), the education sector does not only focus on academic achievement [3] but it is expected to produce trained resources using reasoning, reasoning skills and character in education. An important aspect to be developed is higher order thinking skills [4]. Developing HOTS in learning activities is very beneficial for students as students gain in-depth conceptual knowledge in accessing information and using new languages in explaining it [5].

In light of this need, the government issued the Minister of Education and Culture Ordinance No. 21 of 2016 on Establishing Competency Standards for Graduates, which was amended in 2013. This curriculum emphasizes a scientific approach to encourage students to think metacognitively, creatively, productively and critically, independently and communicatively, in solving problems and applying learning materials [6]. Higher order thinking skills can be expanded and developed through the application of problem-based learning. It gives students the opportunity to solve various complex, contextual, and poorly structured problems [7]. This offers students the opportunity to develop analytical, evaluative, and reflective thinking skills [8]. In addition, students will have the ability to develop their creativity in exploring different information, developing different possible solutions, and creating different sources to solve problems that need to be solved. So that students can analyze and evaluate more complex systems [9]. In this PBL, the developed higher order thinking skills are critical and creative thinking [10].

Critical thinking components can have the same components as scientific process skills, which include observing, hypothesis testing, predicting, classifying, designing experiments, measuring, analyzing, and synthesizing. Scientific process skills can be improved through practical activities [11]. Based on references [12] several madrasah schools in NTB are still low, 
namely the ability to interpret (38.55\% and $40.47 \%)$; analysis $(30.08 \%$ and $31.28 \%)$; synthesis $(25.70 \%$ and $30.25 \%)$; rating (32.03 and $34.45 \%)$; completed (25.27 and $29.53 \%$ ); conclusion (35.10\% and $37.21 \%$ ); and explanation $(35.24 \%$ and $39.53 \%)$. This is because learning activities have not been optimal for doing practical activities, using technology and solving problems of daily living.

Based on the above problems, innovation is required to apply technology to problem-solving activities in internship activities by focusing students as studentcentered [13]. One of the materials in physics class that requires technology and problem solving related to daily life is the material of mechanics, especially the subject of movement. Experiments that are often done are still easy with imprecise equipment, so that this can be an obstacle to the smooth flow of practical activities. Experimental activities are rarely carried out, so that teachers are more likely to teach students by giving formulas. This results in the student's understanding of concepts and thinking skills not being developed [14].

We need a breakthrough in developing innovative learning media through the use of technologies like sensors and computers that are packaged in problembased learning. The medium is the Motion Sensor Experiment (MSE) in PBL. This medium is used by students as an efficient learning platform for conducting experiments and becomes an alternative to traditional laboratories as users can conduct experiments effectively. Experiment with more precise tools and embed abstract concepts in everyday life. So that it encourages students to solve problems. Based on the above description, the author conducted research to renew MSE in PBL to promote higher order students' thinking skills

\section{RESEARCH METHODS}

\subsection{Design motion sensor experiment}

This research is classified as research and development. The designed model in this study was Borg and Gall. The steps are as follow: 1) Preliminary investigation 2) Prototype, and 3) Testing, the steps are visually presented in Figure 1.

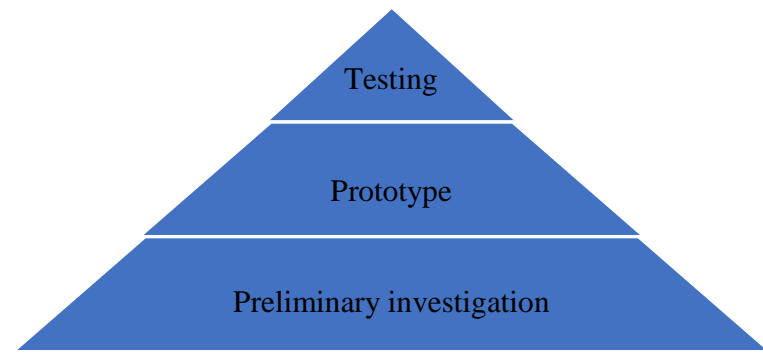

Figure 1 Borg and Gall development [15]
The rolling motion tool in problem based learning products before use was validated with a product validation questionnaire using a Likert scale. The data obtained from the evaluation of material experts, media and teachers are then added up and the total number of points obtained is converted into qualitative data using a five-point scale.

In addition, validation is also carried out with media experts and material experts to see the suitability of the material with the content, the correctness of concepts and materials, the durability of the tools and aspects of thinking skills. Then the students' perception data was taken to see the clarity of the simulation in the experiment, the attractiveness of the simulation, the suitability of the simulation with the material, the clarity of the sentence, the suitability of the example with the material, the ease of learning, interest and motivation in using the tool. The criteria of the tool is based on table 1

Table 1. Criteria of Tools

\begin{tabular}{|l|l|}
\hline Research percentage & Criteria \\
\hline $80 \%-100 \%$ & Strongly agree \\
\hline $60 \%-79,99 \%$ & Agree \\
\hline $40 \%-59,99 \%$ & Doubtful \\
\hline $20 \%-39,99 \%$ & Disagree \\
\hline $0-19,99 \%$ & Strongly Disagree \\
\hline
\end{tabular}

\subsection{Measurement of higher order thinking skill}

The research design used was a pre-test post-test control group design using the method of randomizing two groups as shown in Table 2 [11]:

Table 2. Research Design

\begin{tabular}{|l|c|l|l|}
\hline \multirow{2}{*}{ Group } & \multicolumn{3}{|c|}{ Design } \\
\cline { 2 - 4 } & Pretest & \multicolumn{1}{|c|}{ Treatment } & \multicolumn{1}{|c|}{ Posttest } \\
\hline $\mathrm{X}^{\mathrm{A}}$ & $\mathrm{T}_{1}$ & $\mathrm{O}$ & $\mathrm{T}_{2}$ \\
\hline $\mathrm{X}^{\mathrm{C}}$ & $\mathrm{T}_{1}$ & $\mathrm{X}$ & $\mathrm{T}_{2}$ \\
\hline
\end{tabular}

The samples in this study consisted of 21 students in class $\mathrm{X}^{\mathrm{A}}$ as the control class and 20 students in class $\mathrm{X}^{\mathrm{C}}$ as the experimental class, which were taken by means of targeted sampling procedures. For high level skills, data collection techniques with essay form tests given at the beginning and at the end of learning. The Higher Order Thinking Skill (HOTS) test is tested for quality first before being carried out with estimation of validity and reliability. To prove its validity, content validity was used using the Aiken formula and Cronbach's alpha reliability estimation. The data analyses were included the followings: 1) describing students' HOTS, (2) 
developing motion sensor experiment in Problem-based learning, and (3) testing effectiveness motion sensor experiment for developing students' HOTS.

First, HOTSP to determine student responses by using classical analysis techniques, the percentage of each level is determined by determining the levels of "very low", "low", "medium", "high" and "very high" with the ideal mean and ideal standard deviation shown in table 3. Calculation of the ideal mean (M) and standard deviation (s) is based on the highest and lowest scores for the tested variables, as shown in equations 2 and 3 [16].

Table 3. Score Interval of Ability Level With

\begin{tabular}{|l|l|l|}
\hline No & Internal of ability & Level \\
\hline 1. & $(M+1,50 s)<X$ & Very high \\
\hline 2. & $\begin{array}{l}(M+0,50 s)<X \leq(M+ \\
1,50 s)\end{array}$ & High \\
\hline 3. & $\begin{array}{l}(M-0,50 s)<X \leq(M+ \\
0,50 s)\end{array}$ & medium \\
\hline 4. & $\begin{array}{l}(M-1,50 s)<X \leq(M-0,50 \\
s)\end{array}$ & Low \\
\hline 5. & $X \leq(M-1,50 s)$ & Very low \\
\hline
\end{tabular}

The data analysis for high-level skills was analyzed by $\mathrm{N}$-gain score.

\section{RESULT AND DISCUSSION}

\subsection{Higher order thinking skill}

Skill assessment scores are presented at very low to very high levels. This is done by assigning a rating category. HOTS test results for all subjects are presented in five levels as shown in table 4.

Table 4. Percentage level of hots'student

\begin{tabular}{|l|l|l|}
\hline No & Level & Percentage (\%) \\
\hline 1. & Very high & 20 \\
\hline 2. & High & 66 \\
\hline 3. & medium & 14 \\
\hline 4. & Low & - \\
\hline 5. & Very low & - \\
\hline
\end{tabular}

It can be seen from the table above that the dominant HOST is at the "Low" level (66\%), while 14\% is "at the moderate level. This also shows that the HOST of students is in the low to moderate category.

\subsection{Developing motion sensor experiment in problem based learning}

Experimental motion sensors include experimental modules and tool kits. Experimental device design consisting of a tool set consisting of rolling motion, moment inertia and energy. This tool consists of LDR and LED, inverting amplifier circuit and Arduino and input display for computer applications using Delphi RAD as shown in Figure 2.

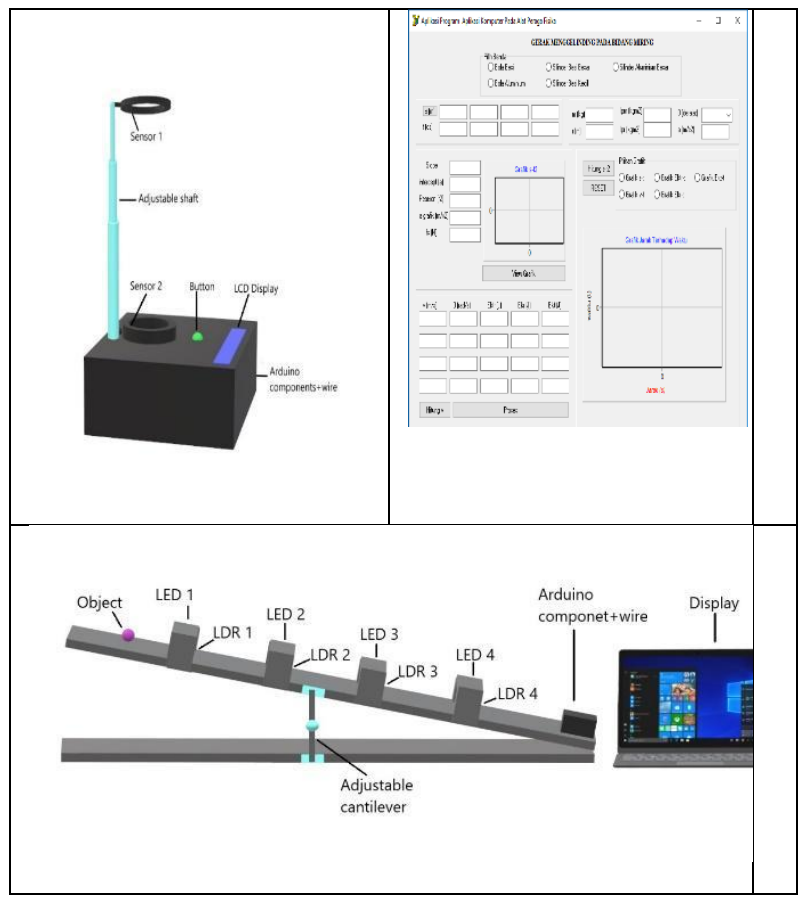

Figure 2 Motion sensor experiment in problem-based learning

The results showed that the motion sensor experiment on movement material was suitable for use in learning. This emerges from the results of the expert validation consisting of 2 lecturers and 2 practitioners. This tools validation activities have been conducted for materials experts, media experts and practitioners. For tool validation activities, the results can be summarized in Figure 3.

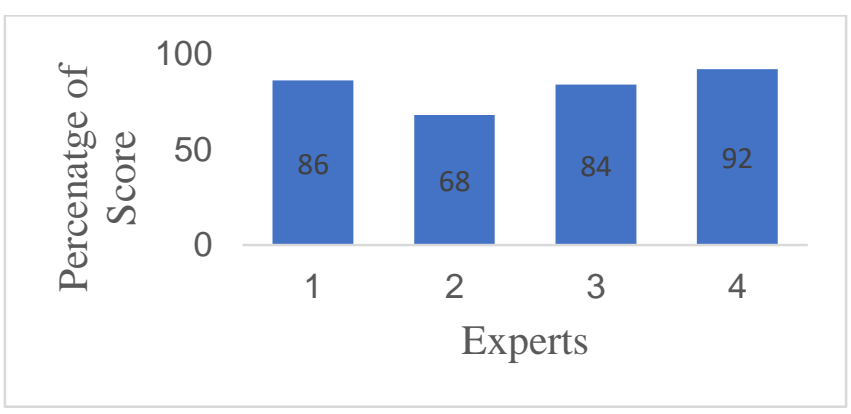

Figure 3 Expert validation results 
From Figure 3 above, the results of the validation of the motion sensor experiments are classified in the appropriate category for use with an average of $82.5 \%$ in terms of module, accuracy, durability, efficiency and aesthetics. For the results of the validation of the motion sensor experiments module in PBL, it is included with an average of $66 \%$ in the corresponding application category with regard to the assessment of aspects of material feasibility, presentation feasibility aspects, language and there is a reference to higher-level thinking skills. Overall, the validated motion sensor experiments in PBL is thus a practicable category that can be used in learning.

\subsection{Testing effectiveness motion sensor experiment in problem based learning for student'HOTS}

The test used were 5 essay questions in line with the higher order thinking skills indicators. Before used, the HOTS questions were validated by 5 experts. Next, we can measure the thinking ability of class X students

Table 5. Aiken's V analysis result for each items

\begin{tabular}{|l|l|l|}
\hline Item Number & Aiken's V & Criteria \\
\hline 1. & 0,90 & high \\
\hline 2. & 0,80 & medium \\
\hline 3. & 0,80 & medium \\
\hline 4. & 0,60 & medium \\
\hline 5. & 0,75 & medium \\
\hline
\end{tabular}

Through the difference in pretest and posttest scores, we can see an increase in students' higher thinking skills

Table 6. Descriptive statistical analysis of student learning outcomes

\begin{tabular}{|l|c|l|l|}
\hline \multirow{2}{*}{\multicolumn{1}{|c|}{ Group }} & \multicolumn{3}{c|}{ Result } \\
\cline { 2 - 4 } & Pretest & \multicolumn{1}{c|}{ Posttest } & \multicolumn{1}{c|}{ Gain } \\
\hline Control class & 3,50 & 13,00 & 0,4 \\
\hline Experiment class & 1,85 & 16,20 & 0,6 \\
\hline
\end{tabular}

In table 6 , it is shown that the average value of pretest experimental control class and experiment class have different. The experiment class gain is higher than control class. So it can be concluded that students who learn to use motion sensor experiments based on computer programs, sensors and microcontrollers in problem-based learning with students who do not use them.

\section{CONCLUSION}

According to the results, it can be concluded that the highest percentage of HOTS levels among students is in the "Low" category (66\%), while medium categories are represented at $14 \%$. The results of expert validation of the developed tools produced an average of $82.5 \%$ in terms of modulus, accuracy, durability, performance and aesthetics. The experiment class gain is also higher than the control class. From this research, it is shown that there are differences in higher order thinking skills between students who study motion sensor experiments in problem-based learning.

\section{ACKNOWLEDGMENTS}

The writers would like to deliver the greatest gratitude to the research institute and community service of Universitas Muhammadiyah Mataram for the financial support.

\section{REFERENCES}

[1] P. L. Ackerman and R. Kanfer, Work in the 21st century: new directions for aging and adult development, Am. Psychol., vol. 75, no. 4, 2020, pp. 486-498, DOI: 10.1037/amp0000615.

[2] B. Kartowagiran and U. N. Yogyakarta, Integrating the 21st Century Character Values for Elementary School Students, Ilkögretim Online, vol. 20, no. 2, 2021, pp. 33-43, DOI: 10.17051/ilkonline.2021.02.07.

[3] N. Ivanova, V. Gugleva, M. Dobreva, I. Pehlivanov, S. Stefanov, and V. Andonova, We are IntechOpen, the world' $\mathrm{s}$ leading publisher of Open Access books Built by scientists, for scientists TOP $1 \%$, Intech, vol. i, no. tourism, 2016, p. 13.

[4] S. Suparman, D. Juandi, and M. Tamur, Does Problem-Based Learning Enhance Students' Higher Order Thinking Skills in Mathematics Learning? A Systematic Review and MetaAnalysis, ACM Int. Conf. Proceeding Ser., 2021, pp. 44-51, DOI: 10.1145/3451400.3451408.

[5] R. Faizah, M. R. A. Taqwa, E. Istiyono, and Ikhsanudin, Senior high school student's higher order thinking skills based on gender and grade," J. Phys. Conf. Ser., vol. 1918, no. 2, 2021, DOI: 10.1088/1742-6596/1918/2/022031.

[6] Y. Suhirman, A. Muliadi, and S. Prayogi, The effect of problem-based learning with character emphasis toward students' higher-order thinking skills and characters, Int. J. Emerg. Technol. 
Learn., vol. 15, no. 6, 2020, pp. 183-191, DOI: 10.3991/IJET.V15I06.12061.

[7] J. L. Pecore, Beyond Beliefs: Teachers Adapting Problem-based Learning to Preexisting Systems of Practice, Interdiscip. J. Probl. Learn., vol. 7, no. 2, 2012, pp. 9-26, DOI: 10.7771/1541-5015.1359.

[8] R. Eka Putra and Iswantir, The Analysis of Implementation of Higher Order Thinking Skills (HOTS) with Problem Based Learning (PBL), J. Phys. Conf. Ser., vol. 1779, no. 1, 2021, DOI: 10.1088/1742-6596/1779/1/012037.

[9] F. King et al., Higher Order Thinking Skills • Definition - Teaching Strategies - Assessment A publication of the Educational Services Program, now known as the Center for Advancement of Learning and Assessment, Voices from Middle, vol. 88, no. 18, , 2003, pp. 495-496.

[10] Nurdyansyah and E. F. Fahyuni, Inovasi Model. 2016.

[11] M. Caroselli, The Critical Thinking Tool Kit. 2011.

[12] Bahtiar, Y. S. Rahayu, and Wasis, Developing Learning Model P3E to Improve Students' Critical Thinking Skills of Islamic Senior High School, $J$. Phys. Conf. Ser., vol. 947, no. 1, 2018, DOI: 10.1088/1742-6596/947/1/012067.

[13] I. A. D. Astuti, D. Dasmo, N. Nurullaeli, and I. B. Rangka, The impact of pocket mobile learning to improve critical thinking skills in physics learning, J. Phys. Conf. Ser., vol. 1114, no. 1, 2018, DOI: 10.1088/1742-6596/1114/1/012030.

[14] J. W. S. D. Sabaryati, Pengembangan Modul Praktikum Fisika Model Guide Inquiry Berbasis Computerized Experiment Tool (Cet) Untuk Pembentukan Karakter Ilmiah Siswa, ORBITA J. Kajian, Inov. dan Apl. Pendidik. Fis., vol. 4, no. 1, 2018, pp. 43-46.

[15] M. G. Lodico, D. T. Spaulding, and K. H. Voegtle, Methods in educational research: from theory to practice.

[16] E. Istiyono, W. Widihastuti, S. Supahar, and S. Hamdi, Measuring Creative Thinking Skills of Senior High School Male and Female Students in Physics (CTSP) Using the IRT-based PhysTCreTS, J. Turkish Sci. Educ., vol. 17, no. 4, pp. 578-590, 2020, DOI: 10.36681/tused.2020.46. 